\title{
GOOD CORPORATE GOVERNANCE (GCG) DAN CORPORATE SOCIAL RESPONSIBILITY (CSR) SEBAGAI DETERMINASI NILAI PERUSAHAAN ( Studi Empiris pada Perusahaan perusahaan LQ45 yang terdaftar di Bursa Efek Indonesia periode 2017 - 2020)
}

\author{
Puput Winningsih ${ }^{1}$ \\ Fakultas Ekonomi Universitas Kisnadwipayana \\ Jalan Unkris Jatiwaringin Jakarta Timur \\ Email : pptwnnngsh@gmail.com \\ Dewi Rejeki \\ Fakultas Ekonomi Universitas Kisnadwipayana \\ Jalan Unkris Jatiwaringin Jakarta Timur \\ Email : dewi.and71@gmail.com
}

\begin{abstract}
This study aims to empirically prove the influence of Good Corporate Governance and Corporate Social Responsibility on firm value in LQ45 companies listed on the Indonesia Stock Exchange for the period 2017 to 2020 both partially and empirically, using several variables, namely Good Corporate Governance with 3 indicators. measurements such as Independent Board of Commissioners, Institutional Ownership, Managerial Ownership and Corporate Social Responsibility. The method used in this research is quantitative which according to the level of explanation includes associative research with a casual approach. The type of data used is secondary data with data sources from audited financial statements, namely LQ45 Companies Listed on the Indonesia Stock Exchange (IDX) based on time series for the period 2017 to 2019. The results of this study partially prove that Good Corporate Governance has no effect. on the value of the company, while Corporate Social Responsibility has an effect on the Firm Value of the Company, while simultaneously Good Corporate Governance and Corporate Social Responsibility have an effect on the Firm Value of the Company.

Keywords : Good Corporate Governance, Corporate Social Responsibility, the Firm Value of the Company
\end{abstract}

\section{PENDAHULUAN}

Banyak perusahaan yang membutuhkan dana tambahan untuk mengembangkan usahanya agar mampu bertahan. Sumber pendanaan dapat diperoleh dengan berbagai cara yaitu, dengan investasi dan pembiayaan dari owners (equity) dan non-owners (liabilities) sehingga atau kegiatan operasional dapat berjalan dengan baik. Tujuan perusahaan adalah memaksimalkan kekayaan atau Nilai Perusahaan bagi para pemegang saham. Nilai Perusahaan (Firm Value) yang go public tercermin pada harga pasar saham perusahaan, sedangkan
Nilai Perusahaan yang belum go public tercermin ketika perusahaan akan dijual.

Nilai Perusahaan yang tinggi akan menarik perhatian para investor untuk menanamkan sahamnya pada perusahaan tersebut. Dalam meningkatkan Nilai Perusahaan, pemegang saham menyerahkan pengelolaan perusahaan kepada pihak manajemen. Peningkatan Nilai Perusahaan didapatkan apabila manajemen mampu menjalin kerjasama yang baik kepeda pihak shareholder dan stokeholder dalam membuat keputusan keuangan. Seorang manajer perusahaan 
mentargetkan perusahaannya mendapatkan laba yang tinggi agar dapat meningkatkan kepercayaan publik terhadap perusahaannya. Nilai Perusahaan yang baik dapat dilihat dari naiknya harga saham di pasar, karena Nilai Perusahaan adalah sebuah tolak ukur bagi para investor untuk menanamkan saham. Semakin tinggi harga saham, maka tingkat kemakmuran dari pemegang saham juga akan meningkat.

Perusahaan pada umumnya memiliki tujuan untuk mendapatkan laba, biasanya dinyatakan dalam bentuk laba persaham. Untuk menilai kekuatan suatu perusahaan adalah analisis keuangan, namun ada pendekatan lain yang tidak kalah penting dalam meningkatkan Nilai Perusahaan yaitu dengan adanya penerapan Good Corporate Governance dan Corporate Social Responsibility dalam perusahaan.

Menurut Agoes (2011) indikator Good Corporate Governance (GCG) yaitu Ukuran Dewan Komisaris, Dewan Komisaris Independen, Kepemilikan Institusional, Kepemilikan Manajerial, dan Komite Audit. Pada penelitian ini ini penulis hanya memilih 3 indikator untuk mengukur Good Corporate Governance, yaitu Dewan Komisaris Independen, Kepemilikan Institusional, Kepemilikan Manajerial.

Suatu perusahan yang memiliki Dewan Komisaris Independen yang dapat meningkatkan Nilai Perusahaan. Dewan komisaris independen adalah seorang yang ditunjuk untuk mewakili pemegang saham independen (pemegang saham minoritas) dan pihak yang ditunjukan tidak dalam kapasitas mewakili pihak manapun dan sematamata ditunjuk berdasarkan latar belakang pengetahuan, pengalaman, dan keahlian professional yang dimilikinya untuk sepennuhnya menjalankan tugas demi kepentingan perusahaan. (Agoes dan Ardana 2014)

Kepemilikan Institusional adalah kepemilikan saham yang dimiliki oleh institusi seperti perusahaan asuransi, bank, perusahaan investasi dan kepemilikan institusional lainnya. kepemilikan institusional yang tinggi mengakibatkan pihak manajemen berhati-hati dalam mengambil keputusan, terutama dalam keputusan pendanaan. (Desiana, 2020)

Sedangkan terdapat juga kepemilikan manajerial maka akan menyatukan kepentingan antara pemegang saham dengan manajer dengan demikian akan mempengaruhi nilai kepercayaan publik terhadap perusahaan tersebut. Kepemilikan saham adalah saham perusahaan yang dimiliki oleh manajemen baik di dalam direksi komisaris maupun karyawan untuk memiliki saham tersebut. Kepemilikan saham berfungsi untuk penyelarasan kepentingan antara pihak - pihak yang berbeda kepentingannya (Azzahrah, 2014).

Selain itu terdapat juga Corporate Social Responsibility yang merupakan suatu konsep akuntansi yang dapat membawa perusahaan agar melaksanakan tanggungjawabnya terhadap lingkungan dan masyarakat. Corporate Social Responsibility memiliki tujuan salah satunya adalah agar perusahaan dapat berkontribusi dalam pelestarian lingkungan sekitar dan pengembangan masyarakat sekitar. Jenis Corporate Social Responsibility yang dilaksanakan perusahaan antara lain adalah program lingkungan, praktik kerja, filantropi, dan sukarelawan. Pelaporan Corporate 
Social Responsibility dapat menggunakan Global Reporting Initiave (GRI).

Nilai Perusahaan dalam penelitian ini diproksikan dengan Price Book Value (PBV). Dipilihnya indikator rasio ini digunakan untuk menilai apakah harga dari saham yang ditawarkan oleh perusahaan adalah harga saham yang mahal atau murah. Price Book Value (PBV) juga berarti rasio yang menunjukkan apakah harga saham yang diperdagangkan overvalued (di atas) atau undervalued (di bawah) nilai buku saham tersebut (Ayuningtias et al., 2013).

Gambar 1. Rata-Rata Tingkat Price Book Value (PBV)

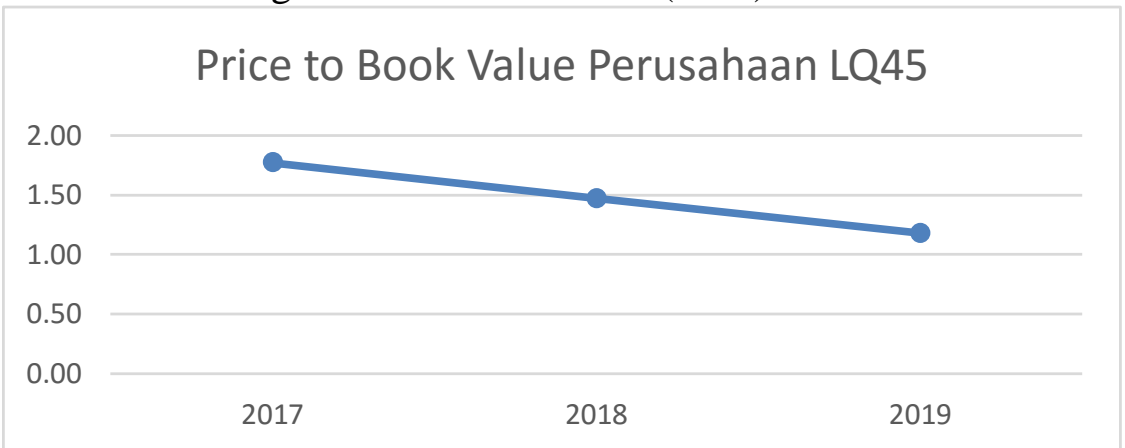

Sumber : Data diolah oleh Peneliti (2021)

Gambar tersebut diatas menggambarkan rata-rata Price Book Value (PBV) perusahaan yang dihitung berdasarkan data Perusahaan LQ45 memiliki prospek yang bagus, karena menghasilkan keuntungan yang bersumber dari pemasukan pajak yang dipungut. Dapat dilihat pada rasio PBV yang menunjukkan rata-rata perusahaan LQ45 tahun 2017 sampai 2019 mengalami penurunan sebesar $1,77 \%$ menjadi $1,18 \%$. Hasil perhitungan menunjukan 5 (lima) perusahaan mengalami penurunan yang drastis secara berturut-turut yaitu PT Bank Tabungan Negara Tbk, PT H.M. Sampoerna Tbk, PT Media Nusantara Citra Tbk, PT PP Tbk, PT Surya Citra Media Tbk. Selain itu Nilai Perusahaan yang dilihat dari rasio PBV menunjukan 3 (tiga) perusahaan LQ45 masih memiliki nilai kurang dari 1 (satu) yang berarti perusahaan LQ45 tersebut dinilai memiliki nilai yang rendah karena para investor membeli

saham lebih murah daripada nilai bukunya.

Pergerakan harga saham dipasar modal merupakan suatu fenomena yang baik untuk dianalisis karena terkait dengan Nilai Perusahaan. Kondisi ekonomi yang tidak stabil akan berdampak buruk pada Nilai Perusahaan. Apabila Nilai Perusahaan buruk dalam laporan keuangan maka investor akan mengurangi jumlah permintaan atas saham perusahaan tersebut. Jika jumlah permintaan saham turun maka akan mengakibatkan harga saham turun, dengan menunjukan harga saham turun maka Nilai Perusahaan tersebut dinilai rendah.

Fenomena di atas menunjukkan bahwa perusahaan LQ45 sedang mengalami penurunan yang diakibatkan belum stabilnnya perekonomian. Adanya beberapa kasus di atas membuktikan pengelolaan perusahaan oleh manajemen memang 
belum dilakukan dengan baik. Manajemen memiliki peranan penting dalam mempertahankan dan meningkatkan nilia perusahaan, karena secara pengetahuan mereka memiliki informasi mengenai kondisi sesungguhnya perusahaan sehingga diharapkan mampu mengelola perusahaan sesuai keinginan pemilik perusahaan.

Penelitian menurut Marius dan Indah (2017) kepemilikan manajerial berpengaruh positif dan tidak signifikan terhadap Nilai Perusahaan, kepemilikan Institusional menunjukkan pengaruh yang negatif dan signifikan terhadap Nilai Perusahaan dan Corporate Social Responsibility berpengaruh positif dan signifikan terhadap Nilai Perusahaan. Sandra (2017) menyatakan bahwa Dewan Komisaris Independen positif dan tidak berpengaruh signifikan terhadap Nilai Perusahaan sedangkan Kepemilikan Institusional dan Corporate Social Responsibility positif dan berpengaruh signifikan terhadap Nilai Perusahaan. Sementara itu Hernanti (2016) yang menjelaskan bahwa kepemilikan institusional memiliki pengaruh positif dan signifikan terhadap Nilai Perusahaan, sedangkan komisaris independen positif dan tidak memiliki pengaruh signifikan terhadap Nilai Perusahaan. Penelitian juga dilakukan oleh Isynuwardhana dan Deannes (2019) menyatakan bahwa secara simultan Good Corporate Governance dan Corporate Social Responsibility berpengaruh secara signifikan terhadap Nilai Perusahaan.

Berdasarkan uraian latar belakang permasalahan yang telah dikemukakan di atas, maka penelitian ini betujuan untuk membuktikan secara empiris Pengaruh Good Corpoorate Governance dan Corporate Social Responsibility terhadap Nilai Perusahaan pada perusahaan LQ45 yang terdaftar di Bursa Efek Indonesia periode 2017 sampai dengan 2020 baik secara parsial maupun secara empiris.

\section{LANDASAN TEORI}

\section{Good Corporate Governance (GCG)}

Good Corporate Governance atau yang biasa disingkat GCG merupakan tata kelola perusahaan hubungan antara berbagai partisipan yang berkepentingan dalam suatu perusahaan untuk menentukan arah tujuan perusahaan yang ingin di capai. Istilah good corporate governance pertama kali dikenalkan oleh Cadbury Committee, Inggris pada tahun 1922 dalam laporannya berjudul Cadbury Report. Kemudian mereka mendefinisikan corporate governance sebagai berikut :

"Sebuah peraturan yang mengatur hubungan antara pemegang saham, pengurus atau pengelola perusahaan, pihak kreditur, pemerintah, karyawan, serta para pemegang kepentingan internal atau eksternal lainnya yang berkatan dengan hak-hak dan kewajiban mereka atau dengan kata lain suatu system yang mengarahkan dan mengendalikan perusahaan" (Hendro, 2012).

Adapun berbagai pengertian lain dari Good Corporate Governance yang dapat dijelaskan sebagai berikut : 
"Good Corporate

Governance sebagai suatu sistem yang mengatur hubungan peran Dewan Komisaris peran Direksi, pemegang saham, dan pemangku kepentingan lainnya. Tata kelola perusahaan yang baik juga disebut sebagai proses yang transparan atas penentuan tujuan perusahaan, pencapainya dan penilaian kinerjanya". (Agoes, 2011)

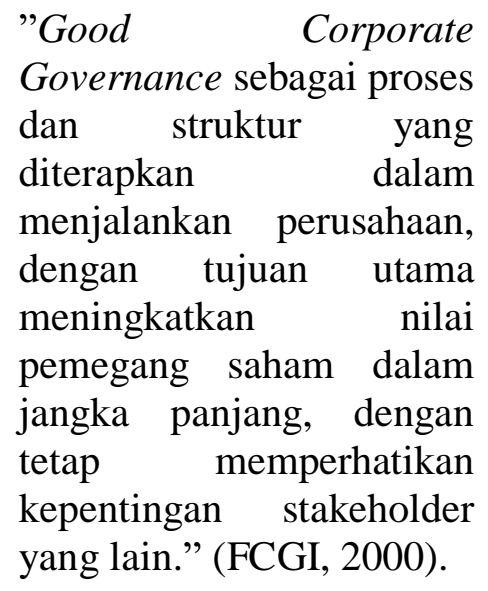

Good Corporate Governance adalah suatu subjek yang memiliki banyak aspek. Salah satu topik utama dalam tata kelola perusahaan adalah menyangkut masalah akuntabilitas dan tanggung jawab atau mandat, khususnya implementasi pedoman dan mekanisme untuk memastikan perilaku yang baik dan melindungi kepentingan pemegang saham.

Tujuan Good Corporate Governance secara umum adalah untuk menciptakan nilai tambah bagi semua pihak yang berkepentingan, yang secara tegas oleh global Good Corporate Governance adalah menjadi sebuah isu penting dunia. Organisasi mempunyai peran kunci untuk bermain dalam peningkatan pengembangan ekonomi sosial. Good Corporate Governance adalah mesinnya pertumbuhan global, pertanggungjawaban penyedia kerja, pelayanan publik dan privat, pengadaan barang dan jasa serta infrastruktur. Sekarang ini, efisiensi akan pertanggung jawaban organisasi tidak peduli apakah organisasi publik atau privat. Good Corporate Governance telah menjadi agenda pokok internasional. Menurut Komite Nasional Kebijakan Governance atau disingkat dengan KNKG (2006), asas Good Corporate Governance (GCG) yaitu : (!) Transparansi, (2) Akuntabilitas, (3) Responsibilitas, (4) Independensi, dan (5) Kewajaran dan Kesetaraan.

Indikator Good Corporate Governance terdiri atas Ukuran Dewan Komisaris, Dewan Independen, Kepemilikan Institusional, Kepemilikan Manajerial, dan Komite Audit (Agoes, 2011).

\section{Corporate Social Responsibility (CSR)}

Corporate Social Responsibility (CSR) pada dasarnya adalah :

"Sebuah kebutuhan bagi korporat untuk dapat berinteraksi dengan komunitas lokal sebagai bentuk masyarakat secara keseluruhan. Kebutuhan korporat untuk beradaptasi dan guna mendapatkan kuntungan sosial dari hubungannya dengan komuitas lokal, sebuah keuntungan sosial berupa kepercayaan (trust)". 
(Bambang dan Famiola, 2013)

Pertanggungjawaban sosial perusahaan diungkapkan di dalam laporan yang disebut sustainability reporting. Sustainability reporting adalah pelaporan mengenai kebijakan ekonomi, lingkungan dan sosial, pengaruh dan kinerja organisasi dan produknya di dalam konteks pembangunan berkelanjutan (sustainable development). Sustainability reporting meliputi pelaporan mengenai ekonomi, lingkungan dan pengaruh sosial terhadap kinerja organisasi (Mulpiani, 2019:6). Sustainability report harus menjadi dokumen strategik yang berlevel tinggi yang menempatkan isu, tantangan dan peluang sustainability development yang membawa menuju kepada core business. Corporate social responsibility (CSR) sebagai sebuah pendekatan dimana perusahaan mengintegrasikan kepedulian sosial dalam operasi bisnis dan dalam interaksi mereka dengan para pemangku tangan kepentingan (stakeholder) berdasarkan prinsip sukarela dan kemitraan.

Tanggung jawab sosial secara lebih sederhana dapat dikatakan sebagai timbal balik perusahaan kepada masyarakat dan lingkungan sekitarnya karena perusahaan telah mengambil keuntungan atas masyarakat dan lingkungan sekitarnya. Proses pengambilan keuntungan tersebut perusahaan seringkali menimbulkan kerusakan lingkungan dan dampak sosial lainnya. Corporate social responsibility (CSR) sebagai bentuk komitmen bisnis untuk memberikan kontribusi perkembangan ekonomi yang berkelanjutan dengan karyawan dan perwakilannya, kominitas lokal dan masyarakat yang luas untuk meningkatkan kualitas hidup, melalui jalan bisnis dan perkembangan yang baik. Soundarya (2015:5) mengatakan bahwa sustainability reporting terbagi menjadi 3 (tiga) kategori yaitu kinerja ekonomi, kinerja lingkungan dan kinerja sosial.

Pengukuran corporate social responsibility (CSR) adalah dengan menilai setiap item yang diungkapkan dalam laporan tahunan perusahaandan atau laporan keberlanjutan. Pengungkapan corporate social responsibility (CSR) yang sesuai dengan standar pedoman pelaporan keberlanjutan GRI (Global Reporting Initiative) terdiri dari 3 (tiga) kategori utama, yang meliputi kinerja ekonomi, lingkungan, dan sosial. Dimana masing-masing item dari ketiga kategori tersebut adalah 9 (kategori ekonomi), 34 (kategori lingkungan) dan 48 (kategori sosial) dan di dalam kategori sosial dibagi lagi menjad subkategori praktek ketenagakerjaan dan kenyamanan bekerja (16 item), subkategori hak asasi manusi (12 item), sub-kategori masyarakat (11 item), sub-kategori tanggungjawab atas produk (9 item). Masing-masing kategori tersebut dinilai 1 jika diungkapkan dan dinilai 0 apabila tidak diungkapkan. Kemudian nilai dari setiap item dijumlahkan untuk memperoleh besarnya nilai corporate social responsibility (CSR) secara keseluruhan dari suatu perusahaandan dibandingkan dengan pedoman standar pelaporan GRI-G4 per kategorinya masing-masing.

Model atau pola corporate social responsibility (CSR) yang umumnya diterapkan oleh perusahaan di Indonesia sedikitnya terdiri dari empat jenis, yaitu : (1) Keterlibatan 
langsung, (2) Melalui yayasan atau organisasi sosial perusahaan, (3) Bermitra dengan pihak lain melalui kerjasama dengan lembaga sosial/organisasi non-pemerintah (NGO atau LSM), instansi pemerintah, universitas atau media massa, baik dalam mengelola dana maupun dalam melaksanakan kegiatan sosialnya (4) Mendukung atau bergabung dalam suatu konsorsium.

\section{Nilai Perusahaan}

Nilai perusahaan sangat penting bagi sebuah perusahaan karena merupakan sebuah persepsi investor terhadap tingkat keberhasilan perusahaan yang dapat dikaitkan dengan harga saham. Harga saham yang tinggi membuat nilai perusahaan juga tinggi, dan meningkatkan kepercayaan pasar tidak hanya pada kinerja perusahaan saat ini tetapi juga untuk masa yang akan datang. Semakin tinggi nilai perusahaan maka semakin tinggi pula tingkat kemakmuran yang diperoleh pemegang saham.

Terdapat beberapa pengertian mengenai nilai perusahaan, yaitu pengertian nilai perusahaan menurut Kamaludin (2011:4) :

"Nilai perusahaan adalah sama dengan harga saham, yaitu apabila jumlah lembar saham dikalikan dengan nilai pasar (market value) per lembar ditambah dengan nilai pasar hutang, maka setiap peningkatan harga saham dengan sendirinya akan menngkatkan nilai perusahaan."

Nilai perusahaan menurut Kusumajaya (2011) merupakan :

"Nilai pasar dari suatu
ekuitas perusahaan
ditambah nilai pasar
hutang, dengan demikian
penambahan dari jumlah
ekuitas perusahaan dengan
hutang perusahaan dapat
mencerminkan
perusahaan".

Nilai perusahaan merupakan salah satu tolak ukur bagi investor dalam melihat kinerja perusahaan dari tahun ke tahun, nilai perusahaan yang tinggi akan membuat investor tertarik untuk menanamkan sahamnya pada perusahaan tersebut. Indikator nilai perusahaan menurut Thomas dan Weston (2004) : (1) Price Book Value (PBV), (2) Price Earning Ratio (PER), dan (3) Tobin's Q.

\section{METODE PENELITIAN}

Penelitian ini adalah jenis penelitian kuantitatif yang menurut tingkat eksplanasinya termasuk penelitian asosiatif dengan pendekatan kasual. Jenis data yang digunakan merupakan data sekunder atau berupa data kuantitatif dengan sumber data dari laporan keuangan yang telah diaudit yaitu Perusahaan LQ45 yang Terdaftar di Bursa Efek Indonesia (BEI) berdasarkan time series periode tahun 2017 sampai dengan tahun 2019 yang diperoleh dari website idx.co.id dan website resmi perusahaan masingmasing.Operasionalisasi variabel bebas dalam penelitian ini adalah Good Corporate Governance dan Corporate Social Responsibility dan variabel terikat adalah Nilai Perusahaa 
Tabel 1 . Operasional Variabel

\begin{tabular}{|c|c|c|}
\hline Variabel & Pengukuran & $\begin{array}{l}\text { Ska } \\
\text { la }\end{array}$ \\
\hline \multirow[t]{3}{*}{$\begin{array}{l}\text { Good } \\
\text { Corporat } \\
\mathrm{e} \\
\text { Governa } \\
\text { nce }\end{array}$} & $\begin{array}{l}\text { Dewan komisaris independen } \\
\text { adalah seorang yang ditunjuk } \\
\text { untuk mewakili pemegang } \\
\text { saham independen } \\
\text { (pemegang saham minoritas) } \\
\text { dan pihak yang ditunjukan } \\
\text { tidak dalam kapasitas } \\
\text { mewakili pihak manapun dan } \\
\text { semata-matar ditunjuk } \\
\text { berdasarkan latar belakang } \\
\text { pengetahuan, pengalaman, } \\
\text { dan keahlian professional } \\
\text { yang dimilikinya untuk } \\
\text { sepennuhnya menjalankan } \\
\text { tugas demi kepentingan } \\
\text { perusahaan. (Agoes dan } \\
\text { Ardana 2014). Rumusnya } \\
\text { sebagai berikut: } \\
\text { jumlah anggota komisarisindeper } \\
\text { jumlah anggota dewankomisar } \\
\text { \% }\end{array}$ & $\begin{array}{l}\text { Ras } \\
\text { io }\end{array}$ \\
\hline & $\begin{array}{l}\text { Kepemilikan institusional } \\
\text { adalah kepemilikan saham } \\
\text { yang dimiliki oleh institusi } \\
\text { seperti perusahaan asuransi, } \\
\text { bank, perusahaan investasi } \\
\text { dan kepemilikan institusional } \\
\text { lainnya. kepemilikan } \\
\text { institusional yang tinggi } \\
\text { mengakibatkan pihak } \\
\text { manajemen berhati-hati } \\
\text { dalam mengambil keputusan, } \\
\text { terutama dalam keputusan } \\
\text { pendanaan. (Desiana, 2020). } \\
\text { Rumusnya sebagai beriikut: } \\
\text { jumlah saham institusi } \\
\text { total saham beredar } \\
\times 100\end{array}$ & $\begin{array}{l}\text { Ras } \\
\text { io }\end{array}$ \\
\hline & $\begin{array}{l}\text { Kepemilikan manajerial yang } \\
\text { akan menyatukan } \\
\text { kepentingan antara pemegang } \\
\text { saham dengan manajer } \\
\text { dengan demikian akan } \\
\text { mempengaruhi r nilai } \\
\text { kepercayaan publik terhadap } \\
\text { perusahaan trsebut. } \\
\text { Kepemilikan saham adalah } \\
\text { saham perusahaan yang } \\
\text { dimiliki oleh manajemen baik } \\
\text { di dalam direksi komisaris } \\
\text { maupun karyawan untuk } \\
\text { memiliki saham tersebut. } \\
\text { Kepemilikan araham } \\
\text { berfungsi untuk penyelarasan }\end{array}$ & $\begin{array}{l}\text { Ras } \\
\text { io }\end{array}$ \\
\hline
\end{tabular}

\begin{tabular}{|c|c|c|}
\hline & $\begin{array}{l}\text { kepentingan antara pihak - } \\
\text { pihak yang berbeda } \\
\text { kepentingannya } \\
\text { (Azzahrah, 2014). } \\
\text { Rumusnya sebagai berikut: } \\
\text { jumlah saham manajemen } \\
\text { total saham beredar } \\
\times 100 \%\end{array}$ & \\
\hline $\begin{array}{l}2 . \\
\text { Corporat } \\
\text { e Social } \\
\text { Responsi } \\
\text { bility } \\
\text { (CSR) }\end{array}$ & 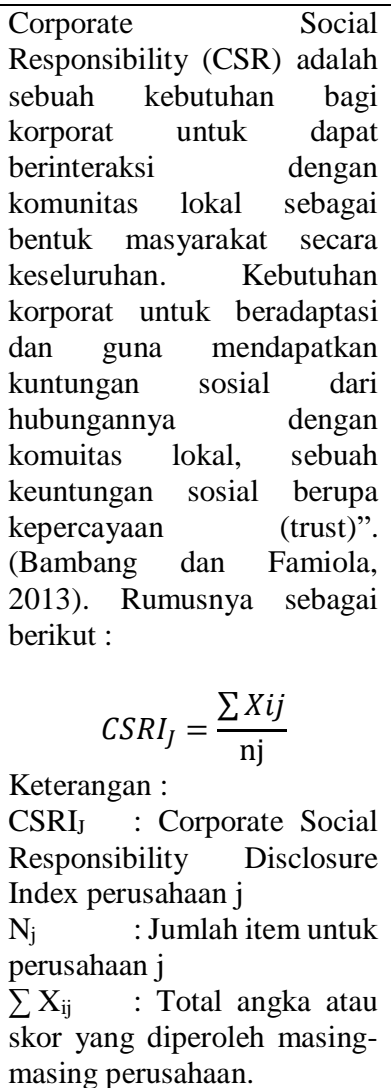 & $\begin{array}{l}\text { Ras } \\
\text { io }\end{array}$ \\
\hline $\begin{array}{l}\text { 3.Nilai } \\
\text { Perusaha } \\
\text { an }\end{array}$ & $\begin{array}{l}\text { Nilai Perusahaan yang } \\
\text { digunakan dalam penelitian } \\
\text { ini adalah Price Book Value } \\
\text { (PBV). Price Book Value } \\
\text { adalah rasio yang } \\
\text { menunjukkan apakah harga } \\
\text { saham yang diperdagangkan } \\
\text { overvalued (di atas) atau } \\
\text { undervalued (di bawah) nilai } \\
\text { buku saham tersebut } \\
\text { (Ayuningtias et al., 2013). } \\
\text { Rumusnya sebagai berikut: } \\
\text { Price Book Value } \\
=\frac{\text { Harga saham }}{\text { Nilai buku }}\end{array}$ & $\begin{array}{l}\text { Ras } \\
\text { io }\end{array}$ \\
\hline
\end{tabular}




\begin{tabular}{|l|l|l|}
\hline & $\begin{array}{l}\text { Untuk mendapatkan nilai } \\
\text { buku, rumusnya adalah } \\
\text { sebagai berikut : }\end{array}$ & \\
\hline
\end{tabular}

Sumber : Data diolah oleh Peneliti (2021)

\section{Populasi, Sampel dan Teknik Pengumpulan Sampel}

Populasi dalam penelitian ini adalah seluruh perusahaan LQ45 yang masuk dalam daftar Bursa Efek Indonsia periode 2017 - 2020 yang berjumlah 45 perusahaan. Teknik pemilihan sampel dilakukan dengan metode purposive sampling dengan tujuan untuk mendapatkan sampel yang representatif sesuai dengan kriteria yang ditentukan, yaitu : (1)Perusahaan LQ45 yang terdaftar di Bursa Efek Indonesia (BEI) selama periode 2017 2019. (2)Perusahaan LQ45 yang menerbitkan dan mempublikasikan laporan keuangan perusahaan selama periode pengamatan dari tahun 20172019.(3)Laporan keuangan yang di sajikan dalam bentuk rupiah tidak

\begin{tabular}{|l|l|l|}
\hline & $\begin{array}{l}\text { Nilai Buku } \\
=\frac{\text { Jumlah ekuitas }}{\text { Jumlah saham beredar }}\end{array}$ & \\
\hline
\end{tabular}

dalam bentuk dollar ataupun mata uang lainnya. (4) Laporan keuangan LQ45 yang menerbitkan Dewan Komisaris Independen, Kepemilikan Institusional, Kepemilikan Manajerial, dan Pengungkapan Corporate Social Responsibility.

Berdasarkan kriteria tersebut diatas diperoleh sampel sebanyak 23 perusahaan, sehingga total sampelnya 69 untuk 3 (tiga) periode. Metode analisis data dalam penelitian ini adalah dengan menggunakan perhitungan statistik, yaitu dengan penerapan SPSS (Statistical Product and Services Solution) for windows 22. Adapun analisis data yang digunakan dalam penelitian ini adalah analisis statistic deskriptif dan analisis regresi linier berganda dengan persamaan regresi adalah sebagai berikut :

$$
Y=\alpha+\beta_{1} X_{1}+\beta_{2} X_{2}+\beta_{3} X_{3}+\beta_{4} X_{4}+\varepsilon
$$

Keterangan :

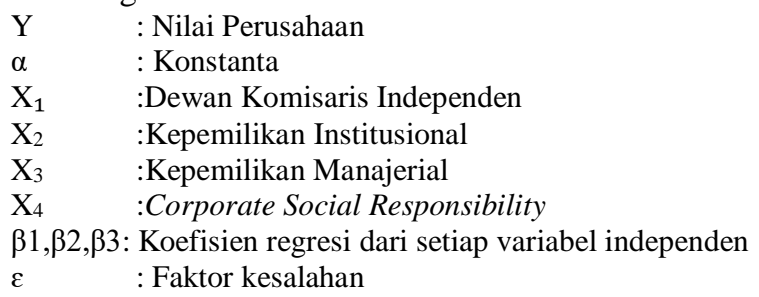

\section{HASIL DAN PEMBAHASAN}

Berdasarkan hasil uji normalitas diperoleh nilai signifikansi (Asymp. Sig) < 0,05 maka data tidak berdistribusi normal, sehingga harus dilakukan screening data dengan cara penghapusan data outlier. Setelah penghapusan data outlier sebanyak 5 
(lima) data, menyebabkan data untuk uji penelitian ini menjadi 64 data dari 22 perusahaan

\section{Analisis Hasil Uji Statistik Deskriptif}

Tabel 2. Hasil Uji Statistik Deskriptif

Descriptive Statistics

\begin{tabular}{|l|l|l|l|l|l|}
\hline & & & & & \\
& $N$ & Minimum & Maximum & Mean & Std. Deviation \\
\hline Dewan Komisaris Independen & 64 &, 54 &, 79 &, 6299 &, 06975 \\
Kepemilikan Institusional & 64 &, 63 &, 87 &, 7641 &, 05729 \\
Kepemilikan Manajerial & 64 &, 00 &, 10 &, 0141 &, 03504 \\
Corporate Social Responsibility & 64 &, 00 &, 90 &, 5534 &, 26840 \\
Price Book Value & 64 &, 10 & 2,87 & 1,4391 &, 56794 \\
Valid N (listwise) & 64 & & & & \\
\hline
\end{tabular}

Sumber :Output SPSS versi 22 (2021)

Berdasarkan hasil pengolahan data diatas diketahui bahwa variabel Dewan Komisaris Independen menunjukkan nilai minimum sebesar 0,54 ; nilai maximum sebesar $0,79 \%$; nilai rata-rata sebesar $0,6299 \%$ dan nilai standar deviasi sebesar $0,6975 \%$.

$$
\text { Variabel Kepemilikan }
$$

Institusional menunjukkan nilai minimumnya sebesar $0,63 \%$; nilai maximumnya sebesar $0,87 \%$; nilai rata-rata sebesar $0,7641 \%$ dengan nilai standar deviasi sebesar 0,05729\%.

$$
\text { Variabel Kepemilikan }
$$

Manajerial menunjukkan nilai minimum yaitu sebesar $0,00 \%$; nilai maximum sebesar $0,10 \%$; nilai ratarata sebesar $0,0141 \%$ dengan nilai standar deviasi sebesar $0,03504 \%$.

\section{Variabel Corporate Social} Responsibility menunjukkan nilai minimum sebesar $0,00 \%$; nilai maximumnya sebesar $0,90 \%$; nilai rata-rata sebesar $0,5534 \%$ dengan nilai standar deviasi sebesar 0,26840\%.

Variabel Price Book Value menunjukkan nilai minimumnya sebesar $0,10 \%$; nilai maximumnya sebesar $2,87 \%$; nilai rata-rata sebesar $1,4391 \%$ dengan nilai standar deviasi sebesar $0,56974 \%$. 


\section{Analisis Regresi Linier Berganda}

Tabel 3. Pengaruh Dewan Komisaris Independen, Kepemilikan

Institusional, Kepemilikan Manajerial dan Corporate Social Responsibility terhadap Nilai Perusahaan

Pengujian Signifikan $\mathrm{F}_{\text {Hitung }}<\mathrm{F}_{\text {Tabel }}=1,447<2,528$

\begin{tabular}{|c|c|c|c|c|c|c|}
\hline Variabel & $\mathrm{R}$ & $\begin{array}{l}\text { Adjusted } \\
\text { R Square }\end{array}$ & Konstanta & $\begin{array}{l}\text { Koefisien } \\
\text { Regresi }\end{array}$ & Sig & $\alpha$ \\
\hline $\begin{array}{l}\text { Dewan Komisaris } \\
\text { Independen } \\
\text { Kepemilikan } \\
\text { Institusional } \\
\text { Kepemilikan } \\
\text { Manajerial } \\
\text { Corporate Social } \\
\text { Responsibility }\end{array}$ & 0,299 & 0,028 & $-0,066$ & $\begin{array}{l}1,653 \\
1,018 \\
-0,780 \\
-0,547\end{array}$ & $\begin{array}{l}0,129 \\
0,421 \\
0,710 \\
0,046\end{array}$ & 0,05 \\
\hline
\end{tabular}

Sumber :Output SPSS versi 22 (2021)

Berdasarkan hasil uji regresi linier berganda diatas, diperoleh persamaan regresi linier berganda sebagai berikut :

$$
\begin{gathered}
Y=-0,066+1,653 X_{1}+1,018 X_{2}- \\
0,780 X_{3}-0,547 X_{4}+e
\end{gathered}
$$

Dengan Nilai Konstanta (a) adalah - 0,066 dengan asumsi variabel lain nilainya tetap, diperoleh nilai koefisien regresi variabel dewan komisaris independen sebesar 1,653. Hal ini dapat diartikan bahwa setiap kenaikan dewan komisaris independen sebesar $1 \%$ maka nilai perusahaan akan meningkat sebesar 1,653. Nilai koefisien regresi variabel kepemilikan institusional diperoleh sebesar 1,018. Hal ini dapat diartikan bahwa setiap kenaikan kepemilikan institusional sebesar $1 \%$ maka nilai perusahaan akan meningkat sebesar 1,018. Nilai koefisien regresi variabel kepemilikan manajerial diperoleh sebesar $-0,780$. Hal ini dapat diartikan bahwa setiap kenaikan kepemilikan manajerial sebesar $1 \%$ maka nilai perusahaan akan mengalami penurunan sebesar 0,780 . Nilai koefisien regresi variabel Corporate Social Responsibility diperoleh sebesar -0,547. Hal ini dapat diartikan bahwa setiap kenaikan pertumbuhan perusahaan sebesar $1 \%$ maka nilai perusahaan akan mengalami penurunan sebesar 0,547.

Sedangkan berdasarkan hasil pengujian signifikansi $\mathrm{F}$ diperoleh nilai F $F_{\text {hitung }}$ sebesar 1,447 dengan probabilitas signifikasi sebesar 0,000. Hal ini dapat diartikan bahwa Dewan Komisaris Independen dan Kepemilikan Institusional secara bersama-sama memiliki pengaruh positif sedangkan Kepemilikan Manajerial dan Corporate Social Responsibility memiliki pengaruh negatif terhadap Nilai Perusahaan. Nilai koefisien determinasi sebesar 0,028, artinya kontribusi yang diberikan variabel Dewan Komisaris Independen, Kepemilikan Institusional, 
Kepemilikan Manajerial dan Corporate Social Responsibility sebesar 2,8\% terhadap Nilai Perusahaan, sedangkan sisanya sebesar 97,2\% disumbangkan oleh faktor lain yang tidak dibahas dalam penelitian ini.

\section{Pembahasan}

Dewan Komisaris Independen tidak berpengaruh terhadap Nilai Perusahaan pada Perusahaan LQ45 yang Terdaftar di BEI tahun 20172019. Hal ini dibuktikan bahwa dengan signifikansi 0,129>0,05 atau Ho Diterima $\mathrm{H}_{1}$ Ditolak. Jadi dapat disimpulkan bahwa Dewan Komisaris Independen secara parsial tidak memiliki pengaruh signifikan terhadap Nilai Perusahaan.

Hasil penelitian ini sejalan dengan hasil penelitian Wardoyo dan Veronica (2013) serta Aryanto dan Setyorini (2019) yang menyatakan bahwa dewan komisaris independen tidak berpengaruh signifikan terhadap nilai perusahaan. Semakin besar ukuran Dewan Komisaris Independen maka perusahaan mengalami masalah koordinasi dan komunikasi, sehingga dalam proses pengambilan keputusan menjadi tidak efektif dan nilai perusahaan menjadi turun.

Kepemilikan Institusional tidak berpengaruh terhadap Nilai Perusahaan pada Perusahaan LQ45 yang Terdaftar di BEI tahun 2017-2019. Hal ini dibuktikan bahwa dengan signifikansi 0,421 > 0,05 atau Ho Diterima $\mathrm{H}_{2}$ Ditolak. Jadi dapat disimpulkan bahwa Kepemilikan Institusional secara parsial tidak memiliki pengaruh signifikan terhadap Nilai Perusahaan.

Hasil penelitian ini sejalan dengan hasil penelitian Srimindarti dan Puspitasari (2014)
Kusumaningtyas dan Andayani (2015) yang menyatakan bahwa kepemilikan institusional tidak berpengaruh signifikan terhadap nilai perusahaan. Hasil ini mencerminkan kurang efektifnya kepemilikan institusional dalam memonitor manajemen perusahaan, sehingga pengendalian perusahaan menjadi rendah dan perilaku opportunistic manajemen meningkat.

The strategic alignment hypothesis menyatakan bahwa investor institusional yang memilki kepemilikan saham mayoritas akan lebih cenderung berpihak dan bekerjasama dengan pihak manajemen untuk mendahulukan kepentingan pribadinya dari pada kepentingan pemegang saham minoritas. Hal ini memberikan sinyal negatif untuk pihak luar karena strategi aliansi investor institusional dengan pihak manajemen cenderung mengambil kebijakan perusahaan secara tidak optimal. Tindakan ini dapat merugikan operasional perusahaan. Hal tersebut memberikan dampak yaitu investor tidak akan tertarik untuk menanamkan modalnya, volume perdagangan saham dan harga saham semakin menurun, serta nilai perusahaan juga akan ikut menurun.

Kepemilikan Manajerial tidak berpengaruh terhadap Nilai Perusahaan pada Perusahaan LQ45 yang Terdaftar di BEI tahun 2017-2019. Hal ini dibuktikan bahwa dengan signifikansi $0,710>0,05$ atau Ho Diterima $\mathrm{H}_{3}$ Ditolak. Jadi dapat disimpulkan bahwa Kepemilikan Manajerial secara parsial tidak memiliki pengaruh signifikan terhadap Nilai Perusahaan.

Hasil penelitian ini sejalan dengan hasil penelitian menurut Nurhayati dan Medyawati (2012) serta 
Wongso (2013) Kepemilikan Manajerial tidak signifikan terhadap nilai perusahaan hal ini disebabkan karena kepemilikan manajerial belum dapat dipandang sebagai mekanisme yang tepat untuk mengurangi konflik kepentingan antara pemilik dan manajer. Manajer biasanya akan mengedepankan kepentingannya sendiri dari pada kepentingan perusahaan.

\section{Corporate}

Social

Respobsibility berpengaruh terhadap Nilai Perusahaan pada Perusahaan LQ45 yang terdaftar di BEI tahun 2017-2019. Hal ini dibuktikan bahwa dengan signifikansi $0,046<0,05$ atau Ho Ditolak $\mathrm{H}_{4}$ Diterima. Jadi dapat disimpulkan bahwa Corporate Social Respobsibility secara parsial memiliki pengaruh signifikan terhadap Nilai Perusahaan.

Hasil penelitian ini sejalan dengan Adnantara (2014) serta Hariati dan Rihatiningtyas (2016) yang menyatakan bahwa menurunnya pengungkapan Corporate Social Responsibility akan meningkatkan nilai perusahaan, karena terkait dengan biaya Corporate Social Responsibility yang tinggi sehingga menurunkan laba perusahaan dengan arah negatif.

Dewan Komisaris Independen, Kepemilikan Institusional, Kepemilikan Manajerial dan Corporate Social Responsibility secara bersama-sama berpengaruh terhadap Nilai Perusahaan. Hal dibuktikan bahwa berdasarkan hasil uji $F_{\text {hitung }}$ sebesar 1,447 lebih kecil dari $F_{\text {tabel }}$ sebesar 2,528 dengan tingkat signifikansi sebesar 0,000 lebih kecil dari $0,05(0,000<0,05)$ atau $\mathrm{Ho}$ Ditolak $\mathrm{H}_{5}$ Diterima.

Hasil penelitian ini sesuai dengan penelitian sebelumnya yang dilakukan oleh Yolan (2021) yang menyatakan bahwa variabel Dewan Komisaris Independen, Kepemilikan Institusional, Kepemilikan Manajerial, dan Corporate Social Responsibility berpengaruh secara simultan terhadap Nilai Perusahaan.

\section{KESIMPULAN}

Berdasarkan analisis dan pembahasan yang telah dilakukan dalam penelitian pada Perusahaan LQ45 yang terdaftar di BEI tahun 2017-2019 dapat disimpulkan bahwa Secara parsial Good Corporate Governance (Dewan Komisaris Independen, Kepemilikan Institusi dan Kepemilikan Manajerial) tidak berpengaruh terhadap Nilai Perusahaan, sedangkan Corporate Social Responsibility berpengaruh Nilai Perusahaan. Secara simultan Good Corporate Governance (Dewan Komisaris Independen, Kepemilikan Institusi dan Kepemilikan Manajerial) dan Corporate Social Responsibility berpengaruh Nilai Perusahaan. 


\section{DAFTAR PUSTKA}

Adnantara, K. (2014). Pengaruh Struktur Kepemilikan Saham Dan Corporate Social Responsibility Pada Nilai Perusahaan. Buletin Studi Ekonomi, 18(2), 107-113.

Agoes, S. (2011). Etika Bisnis dan Profesi. Salemba Empat, 2009.

Amaliyah, F., dan dan Herwiyanti, E. (2019). Pengaruh Kepemilikan Institusional, Dewan Komisaris Independen, dan Komite Audit terhadap Nilai Perusahaan Sektor Pertambangan. Akuntansi, 9.

Ardana, S. A. I. C. (2014). Etika Bisnis dan Profesi : Tantangan Membangun Manusia. Salemba Empat.

Aryanto, A., dan Setyorini, C. T. (2019). Pengaruh Tata Kelola Perusahaan Dan Tanggung Jawab Sosial Terhadap Nilai Perusahaan Sektor Pertambangan. Jurnal Informasi, Perpajakan, Akuntansi, Dan Keuangan Publik, 14(2), 181. https://doi.org/10.25105/jipak.v1 $4 \mathrm{i} 2.5020$

Ayuningtias, Dwi, dan Kurnia. (2013). Penggaruh Profitabilitas Terhadap Nilai Perusahaan: Kebijakan Deviden Dan Kesempatan Investasi Sebagai Variabel Antara. Jurnal Ilmu Dan Riset Akuntansi, 1.

Azzahrah, Y. (2014). Pengaruh Mekanisme Good Corporate Governance terhadap Nilai Perusahaan (Studi pada sektor perkbankan yang terdaftar di Bursa Efek Indonesia tahun 20092013). Akuntansi.

Desiana, F. (2020). Kajian dan Solusi Manajemen Berbasis Riset.

FCGI. (2000). Peranan Dewan Komisaris dan Komite Audit dalam Pelaksanaan Corporate
Governance ( Tata Kelola Perusahaan ).

Ghozali, I. (2018a). Aplikasi Analisis Multivariate dengan Program IBM SPSS 25. Badan Penerbit Universitas Diponegoro.

Ghozali, I. (2018b). Aplikasi Analisis Multivariate dengan Program IMB SPSS 25 (9th ed.). Badan Penerbit Universitas Diponegoro.

Global Reporting Initiative. (2016). Pedoman Pelaporan Keberlanjutan G4: Prinsip-Prinsip Pelaporan dan Pengungkapan Standar. In Global Reporting Initiative.

Hariati, I., dan Rihatiningtyas, Y. W. (2016). Pengaruh Tata Kelola Perusahaan Dan Kinerja Lingkungan Terhadap Nilai Perusahaan. Jurnal Akuntansi dan Keuangan Daerah, 11(2), 52-59.

Hendro, sigit tri. (2012). Etika Bisnis Modern: pendekatan pemangku kepentingan. Unit penerbit dan pencetakan Sekolah Tinggi Ilmu Manajemen YKPN.

Hernanti. (2016). This study aims to reexamine the effect of good corporate governance variables and corporate social responsibility disclosure on firm value. The population in this study are manufacturing companies listed on the Indonesia Stock Exchange in the 2015-2017 p. Jurnal Ilmiah Akuntansi Dan Bisnis, 11(1), 5462.

Isynuwardhana, M., dan Deannes, A. F. (2019). Pengaruh Good Corporate Governance Dan Corporate Social Responsibility Terhadap Nilai Perusahaan (Studi Pada Perusahaan Sektor Industri Barang Dan Konsumsi Yang 
Terdaftar Di Bursa Efek Indonesia Tahun 2014-2017). Journal of Chemical Information and Modeling, 3, 89-100.

KNKG. (n.d.). Pedoman umum good corporate governance indonesia. 2006, 634.

Kusumajaya. (2011). Pengaruh Struktur Modal dan Pertumbuhan Perusahaan terhadap Profitabilitas dan Nilai Perusahaan pada Perusahaan Manufaktur di Bursa Efek Indonesia. Universitas Udayana.

Kusumaningtyas, T. K., dan Andayani. (2015). Pengaruh Good Corporate Governance terhadap Nilai Perusahaan yang terdaftar pada indeks SRI-Kehati. 4(7), 1-16.

Marius, M. E., dan Indah, M. (2017). Pengaruh Good Corporate Governance dan Corporate Social Responsibility terhadap Nilai Perusahaan. Konferensi Ilmiah Akuntansi IV.

Mulpiani, W. (2019). Pengaruh Pengungkapan Sustainability Report Terhadap Kinerja Perusahaan Publik di Indonesia. Jurnal Akuntansi Bisnis, 2, 77-90. https://doi.org/10.24167/jab.v17i 1.2284

Mutmainah. (2015). Analisis Good Corporate Governance Terhadap Nilai Perusahaan. E-Journal Stiedewantara, Vol. X(No.2, Oktober), $\quad$ pp: 1-15. http://ejournal.stiedewantara.ac.id Ningrum, R. A., Fachrurrozie, F., dan Jayanto, P. Y. (2013). Pengaruh Kinerja Keuangan, Kepemilikan Institusional Dan Ukuran Dewan Pengawas Syariah Terhadap Pengungkapan Isr. Journal Of Accounting, 2(4), 430-438. https://doi.org/10.15294/aaj.v2i4.
4169

Nurhayati, dan Medyawati. (2012). Analisis Pengaruh Kinerja

Keuangan, Good Corporate Governance Dan Corporate Social Responsibility Terhadap Nilai Perusahaan Yang Terdaftar Dalam LQ45 pada Tahun 20092011. Jurnal Akuntansi, 1, 1-13.

Rimardhani, H., Hidayat, R., dan Dwiatmanto, D. (2016). Pengaruh Mekanisme Good Corporate Governance Terhadap Profitabilitas Perusahaan (Studi Pada Perusahaan Bumn Yang Terdaftar Di Bei Tahun 20122014). Jurnal Administrasi Bisnis S1 Universitas Brawijaya, 31(1), 167-175.

Rudito, Bambang dan Famiola, M. (2013). CSR (Corporate Social Responsibility). 14 Maret 2014.

Sandra, M. (2017). Pengaruh Good Corporate Governance Dan Corporate Social Responsibility Terhadap Nilai Perusahan Pada Subsektor Kimia Yang Terdaftar Di Bursa Efek Indonesia. Journal Finance Accounting, 1(11), 19601971.

http://journal.widyadharma.ac.id/i ndex.php/finacc/article/view/499

Setyosari, P. (2016). Metode Penelitian Pendidikan dan Pengembangan. Prenada Media.

Sholekah, F. W., dan Venusita, L. (2014). Pengaruh Kepemilikan Manajerial, Kepemilikan Institusional, Leverage, Firm Size, Dan Corporate Social Responsibility Terhadap Nilai Perusahaan Pada Perusahaan High Profile yang Terdaftar di Bursa Efek Indonesia Periode 20082012. Jurnal Ilmu Manajemen, 2(3), 795-807. 
Soundarya, S. (2015). Corporate Social Responsibility: A Contemporary Approach Towards Sustainable Development. IOSR Journal of Business and Management, 4043.

Srimindarti dan Puspitasari. (2014). Peran Kepemilikan Institusional, Komisaris Independen, Komite Audit dan Auditor Eksternal terhadap Integritas Laporan Keuangan. Jurnal Akuntansi Aktual.

Sugiyono. (2016). Metode Penelitian Kuantitatif, Kualitatif dan RdanD. PT Alfabet.

Sukirni, D. (2012). Kepemilikan Manajerial, Kepemilikan Institusional, Kebijakan Deviden Dan Kebijakan Hutang Analisis Terhadap Nilai Perusahaan. Accounting Analysis Journal, 1(2).

https://doi.org/10.15294/aaj.v1i2. 703

Sunyoto, D. (2016). Metodologi Penelitian Akuntansi. PT Refika Aditama.

Thomas, dan J., C. W. (2004). Manajemen Keuangan (9th ed.). Rineka Cipta.

Wardoyo, dan Veronica, T. M. (2013).
Pengaruh Good Corporate Governance, CSR dan Kinerja Keuangan terhadap Nilai Perusahaan. Jurnal Dinamika Manajemen, 4(2), 132-149. http://journal.unnes.ac.id/nju/inde x.php/jdm

Widarjo, Bandi, H. (2010). Pengaruh Ownership Retention, Investasi dari Proceeds, dan Reputasi Auditor Terhadap Nilai Perusahaan dengan Kepemilikan Manajerial dan Institusional sebagai Variabel Pemoderasi. Akuntansi, 1-23.

Wongso, A. (2013). Pengaruh Kebijakan Dividen, Struktur Kepemilikan, dan Kebijakan Hutang terhadap Nilai Perusahaan dalam Perspektif Teori Agensi dan Teori Agensi dan Teori Signaling. Jurnal Ilmiah Mahasiswa Manajemen, 1(5), 16.

Yolan, D. (2021). Pengaruh Good Corporate Governance dan Corporate Social Responsibility terhadap Nilai Perusahaan pada sektor barang konsumsi yang tercatat di BEI periode tahun 2015-2019 Yolan Dahlia. 07(01), $1-6$ 